\title{
PEMISAHAN ASAM AMINO DARI LIMBAH CAIR PABRIK KELAPA SAWIT DENGAN KROMATOGRAFI PENUKAR ION
}

\author{
Indah Rahmi Sari ${ }^{1)^{*}}$,Ade Ayu Oksari ${ }^{2)}$, Irma Kresnawaty ${ }^{3)}$ \\ ${ }^{1)}$ Alumni Program Studi Kimia FMIPA Universitas Nusa Bangsa Bogor \\ ${ }^{2)}$ Program Studi Biologi FMIPA Universitas Nusa Bangsa Bogor \\ ${ }^{3)}$ Pusat Penelitian Bioteknologi dan Bioindustri Indonesia (PPBBI) \\ e-mail : indahrsari@yahoo.co.id
}

\begin{abstract}
Separation of Amino acid from Liquid waste of Oil palm Factory with Ion Exchange Chromatography
\end{abstract}

\begin{abstract}
Research on Separation of Amino Acid Liquid Waste mills with Ion Exchange Chromatography was carried out from October to November 2015. The results of hydrolysis of $6 \mathrm{~N} \mathrm{HCl} \mathrm{results} \mathrm{showed} \mathrm{that} \mathrm{the} \mathrm{highest}$ absorbance reading was obtained at a concentration of eluent of 0,2 and 0,6 $\mathrm{M} \mathrm{NaCl}$, while the results of the protease enzyme hydrolysis the highest absorbance reading at $\mathrm{NaCl}$ eluent 0,2 and $1 \mathrm{M}$. There was no significant difference in the results of separation by ion exchange chromatography, showed that the concentration of $\mathrm{NaCl}$ eluent is not very influential, so for subsequent analysis used only one concentration of the eluent. Results of linear regression obtained was equal to 0,9946, these results indicate that the series standard amino acid lysine has a value that is linear as it approaches 1. The amino acid levels obtained on the sample results LCPKS hydrolysis with $6 \mathrm{~N}$ $\mathrm{HCl}$ which was about 0 to $8.82 \mathrm{ppm}$ and samples of the protease enzyme hydrolysis of about 0 to $4.31 \mathrm{ppm}$. Amino acid levels obtained were still far from the expected.
\end{abstract}

Keywords: Amino Acid, Oil Palm, Liquid Waste, Ion Exchange Chromatography

\begin{abstract}
ABSTRAK
Penelitian mengenai Pemisahan Asam Amino dari Limbah Cair Pabrik Kelapa Sawit dengan Kromatografi Penukar Ion telah dilaksanakan dari bulan Oktober sampai November 2015. Hasil hidrolisis HCl $6 \mathrm{~N}$ menunjukkan bahwa pembacaan absorbansi tertinggi diperoleh pada konsentrasi eluen $\mathrm{NaCl} 0,2$ dan $0,6 \mathrm{M}$, sedangkan hasil hidrolisis enzim protease pembacaan absorbansi tertinggi pada eluen $\mathrm{NaCl} 0,2$ dan $1 \mathrm{M}$. Tidak ada perbedaan yang signifikan pada hasil pemisahan dengan kromatografi penukar ion ini, menunjukkan bahwa konsentrasi eluen $\mathrm{NaCl}$ tidak terlalu berpengaruh, sehingga untuk analisis selanjutnya digunakan hanya satu konsentrasi eluen. Hasil regresi linear yang diperoleh yaitu sebesar 0,9946, hasil tersebut menunjukkan bahwa deret standar asam amino lisin mempunyai nilai yang linear karena mendekati 1 . Kadar asam amino yang diperoleh pada sampel hasil hidrolisis LCPKS dengan $\mathrm{HCl} 6 \mathrm{~N}$ yaitu sekitar $0-8,82 \mathrm{ppm}$ dan sampel hasil hidrolisis enzim protease sekitar $0-4,31 \mathrm{ppm}$. Kadar asam amino yang diperoleh masih jauh dari yang diharapkan.
\end{abstract}

Kata Kunci: Asam Amino, Minyak Kelapa Sawit, Limbah Cair, Kromatografi Penukar Ion

\section{PENDAHULUAN}

Salah satu komoditas perkebunan strategis Indonesia pada saat ini adalah tanaman kelapa sawit. Indonesia adalah penghasil minyak kelapa sawit terbesar di dunia dan penyebarannya antara lain di daerah Aceh, pantai timur Sumatera, Jawa, Kalimantan, dan Sulawesi. Kelapa sawit (Elaeis) adalah tumbuhan industri penting penghasil minyak masak, minyak industri, maupun bahan bakar (biodiesel). Perkebunan kelapa sawit memiliki potensi menghasilkan keuntungan besar sehingga banyak hutan dan perkebunan lama dikonversi menjadi perkebunan kelapa sawit. Industri kelapa sawit merupakan salah satu industri yang berkembang pesat pada dua dekade terakhir dan diproyeksikan masih akan tetap menjadi salah satu sub sektor perkebunan pada masa mendatang (Hidayanto, 2007). 
Proses pengolahan kelapa sawit menjadi minyak kelapa sawit akan menghasilkan limbah cair dalam jumlah yang cukup besar. Sebanyak 1 ton minyak kelapa sawit menghasilkan 2,5 ton limbah cair pabrik minyak kelapa sawit (Hidayanto, 2007). Limbah cair tersebut berasal dari proses perebusan, klarifikasi dan hidrosiklon. Pengembangan industri kelapa sawit yang diikuti dengan pembangunan pabrik, dapat menimbulkan dampak negatif terhadap lingkungan berupa pencemaran terhadap lingkungan perairan.

Karakteristik limbah cair dari kegiatan industri pabrik kelapa sawit seperti Biological Oxygen Demand (BOD) sebesar 135,80 mg/L, Chemical Oxygen Demand (COD) sebesar 394,7 mg/L, Total Solid suspensed (TSS) sebesar 271, $5 \mathrm{mg} / \mathrm{L}$ dan pH 4,1. Baku mutu BOD sebesar $100 \mathrm{mg} / \mathrm{L}$, baku mutu COD sebesar $350 \mathrm{mg} / \mathrm{L}$, baku mutu TSS sebesar $250 \mathrm{mg} / \mathrm{L}$ dan baku mutu pH 6,0 - 9,0 (Satria, 1999). Keadaan ini menunjukkan bahwa angka-angka tersebut berada di atas toleransi baku mutu yang direkomendasikan, jika dibuang ke badan air akan mengganggu ekosistem serta kualitas kandungan air tanah karena sebagian akan mengendap, terurai secara perlahan, mengkonsumsi oksigen terlarut, menimbulkan kekeruhan, mengeluarkan bau yang tajam dan dapat merusak ekosistem badan penerima (Alaerts, 1987; Betty, 1996). Masalah lain yang timbul yaitu tidak semua industri kelapa sawit dapat mengolah limbah sendiri atau dengan kata lain tidak semua memiliki Instalasi Pengolahan Air Limbah (IPAL) yang memadai. Syarat IPAL yang memadai yaitu harus memiliki proses oil separation tank, anaerobic reactor, aerobic reactor, settling tank, dan receiving tank (Rahardjo, 2005).

Pencemaran lingkungan yang terjadi akibat Limbah Cair Pabrik Kelapa Sawit (LCPKS) ini dapat diatasi dengan penanganan yang tepat, salah satunya adalah memanfaatkan hasil sampingan yang terkandung didalamnya. Hasil sampingan LCPKS yang memiliki potensi besar untuk diolah dan dimanfaatkan adalah kandungan bahan organik. LCPKS mengandung berbagai senyawa yang berpeluang untuk dapat diekstrak kembali dan dikemas menjadi produk bernilai ekonomi yang cukup tinggi. Utomo dan Widjaja (2004) mengemukakan bahwa kandungan nutrien dalam residu LCPKS adalah lemak, protein dan karbohidrat.

Menurut Habib et al. (1997), LCPKS mengandung asam amino esensial seperti fenilalanin, metionin, leusin dan lisin dalam jumlah tinggi, serta histidin dan tirosin dalam jumlah kecil. Di samping itu, LCPKS juga mengandung sejumlah asam amino non esensial seperti asam aspartat, asam glutamat, serin, glisin dan sistein dalam jumlah tinggi. Asam amino inilah yang merupakan sumber nutrisi tambahan bagi makhluk hidup. Aplikasi LCPKS memiliki keuntungan diantaranya adalah mengurangi terjadinya pencemaran lingkungan, mengurangi biaya pengolahan limbah cair dan sekaligus berfungsi sebagai sumber hara bagi tanaman kelapa sawit dan nutrisi tambahan bagi pupuk dan pakan ternak.

Asam amino sangat diperlukan oleh tubuh karena merupakan prekursor berbagai senyawa yang berperan penting baik sebagai nutrisi tubuh maupun untuk mempertahankan kesehatan manusia dan hewan. Industri dan volume pasar asam amino juga berkembang pesat dalam 20 tahun terakhir. Menurut hasil studi yang dilakukan oleh Business Communication Company (Brown et al., 2005), pasar asam amino meningkat rata-rata $7 \%$ per tahun dan pada tahun 2009 akan mencapai nilai satu miliar Dolar Amerika. Dengan demikian maka pemisahan asam amino dari LCPKS akan memberikan dampak positif dalam mengatasi masalah pencemaran lingkungan dan memberikan nilai tambah kepada pabrik pengolahan minyak kelapa sawit.

Berdasarkan hasil penelitian Utomo dan Widjaja (2004), menunjukkan bahwa produksi limbah perkebunan kelapa sawit secara fisik cukup potensial sebagai sumber pakan ternak dengan kandungan protein kasar sebesar 12,63\%. Penelitian tentang limbah cair pabrik kelapa sawit lain yaitu diaplikasikan untuk menghasilkan biogas. Penelitian yang dilakukan oleh Mahajoeno et al. (2007) menunjukkan bahwa total produksi biogas tertinggi pada LCPKS 
sebesar $121 \mathrm{~L}$ dan residu dari biogas tersebut dapat dimanfaatkan sebagai pupuk organik non fitotoksin.

\section{BAHAN DAN METODE}

\section{Bahan dan Alat}

Bahan-bahan yang digunakan pada analisis ini yaitu sampel hasil hidrolisis LCPKS menggunakan $\mathrm{HCl} 6 \mathrm{~N}$ dan enzim protease, matriks: DEAE (Dietilaminoetanol), buffer fosfat sitrat $20 \mathrm{mM}$ pH 5,0; $\mathrm{NaCl}, \mathrm{HCl} 1 \mathrm{M}$, aquadest, piridin $10 \%$, ninhidrin $2 \%$, dan larutan induk lisin 500 ppm.

Alat-alat yang digunakan yaitu kolom Syringe $5 \mathrm{~mL}$ dengan diameter 2,5 $\mathrm{cm}$ dan tinggi $10 \mathrm{~cm}$, botol vial $2 \mathrm{~mL}$, statif dan clamp, pipet mikro $1000 \mu \mathrm{L}$, dan spektrofotometer UV/VIS merk Multiskan Go Double Beam versi 100.40.

\section{Persiapan dan Penyetimbang Kolom}

Kolom syringe, statif dan clamp disiapkan. Clamp dan statif yang sudah terpasang dihubungkan dengan kolom. Air dimasukkan pada kolom dan ditempatkan kapas pada bagian dasar kolom. Kolom diisi dengan $3 \mathrm{~mL}$ matriks DEAE Toyopearl yang telah dilarutkan dengan

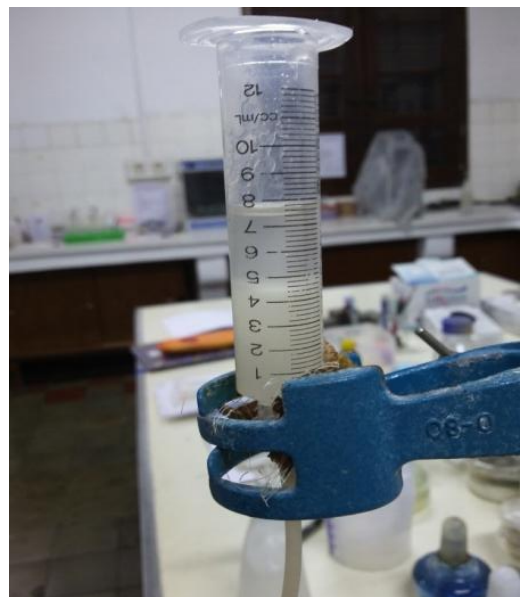

(a)
$\mathrm{HCl} 1 \mathrm{M}$. Beberapa saat didiamkan dan kran dibuka sehingga air akan menetes secara perlahan (ditampung dalam tabung reaksi). Kran ditutup ketika terbentuk larutan jernih di atas matriks kolom (kolom tidak boleh kering) dan didiamkan beberapa saat hingga matriks padat dan setimbang (Anonimous, 2014).

\section{Pemisahan dengan Kromatografi Penukar Ion}

Sampel hasil hidrolisis LCPKS dengan $\mathrm{HCl} 6 \mathrm{~N}$ dan enzim protease disiapkan masing-masing sebanyak $1 \mathrm{~mL}$ dan dilarutkan 1,5 mL larutan buffer fosfat sitrat $\mathrm{pH} 5$ dalam gelas piala $50 \mathrm{~mL}$. Sebanyak 0,5 $\mathrm{mL}$ sampel dimasukkan ke dalam kolom secara perlahan. Kran dibuka lagi sampai semua sampel masuk ke dalam gel. Kolom dielusi dengan peningkatan konsentrasi garam $\mathrm{NaCl} 0,2 ; 0,4 ; 0,6 ; 0,8$ dan 1,0 M sebanyak $10 \mathrm{~mL}$. Setiap sampel yang keluar dari kolom ditampung pada 4 tabung reaksi (setiap botol berisi $\pm 2,5 \mathrm{~mL}$ ). Setiap sampel diukur menggunakan spektrofotometer UV-VIS pada $\lambda 280 \mathrm{~nm}$. Grafik hasil kromatografi dibuat. Sampel dimasukkan dalam tabung reaksi dan ditutup dengan alufo kemudian dilakukan perlakuan pada tahap selanjutnya (Anonimous, 2014).

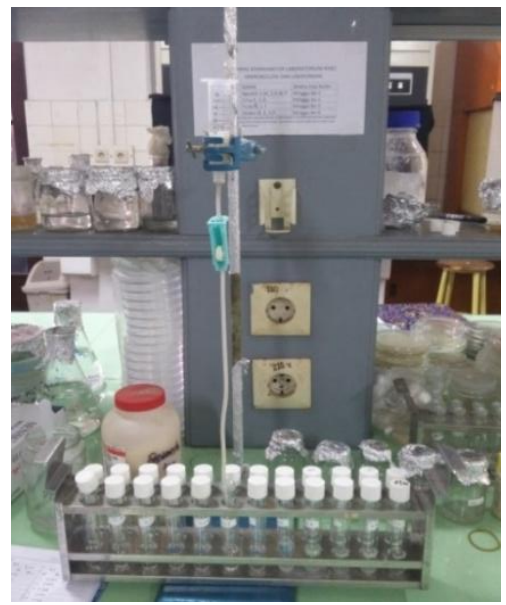

(b)

Gambar 5. (a) Kolom Syringe; (b) Pemisahan dengan Kromatografi Penukar Ion 


\section{Pengukuran Kadar Asam Amino}

Deret standar asam amino $(0-$ $200 \mathrm{ppm}$ ) dan blanko dibuat dari larutan induk asam amino lisin $500 \mathrm{ppm}$. Sampel hasil kromatografi masing-masing dipipet sebanyak $1 \mathrm{~mL}$, kemudian masing-masing deret standar, blanko dan sampel hasil kromatografi dimasukkan dalam labu ukur $10 \mathrm{~mL}$. Setelah itu ditambahkan $0,5 \mathrm{~mL}$ piridin $10 \%$ dan $0,5 \mathrm{~mL}$ ninhidrin $2 \%$. Dipanaskan dalam penangas air mendidih selama 20 menit sampai terjadi perubahan warna menjadi biru. Setelah dingin semua deret standar, blanko dan sampel ditambahkan air suling hingga volume 10 $\mathrm{mL}$. Deret standar, blanko dan sampel diukur absorbansi menggunakan spektrofotometer pada $\lambda 625 \mathrm{~nm}$. Konsentrasi tiap sampel dihitung dengan cara (Hidayati, 2007):

$$
\mathrm{ppm}=\frac{\text { abs (sampel)-intercept }}{\text { slope }} \times \mathrm{fp}
$$

Keterangan:

$$
\begin{array}{ll}
\operatorname{ppm} & =\text { konsentrasi sampel } \\
\text { slope } & =\text { hasil pembacaan pada grafik } \\
\text { abs } & =\text { absorbansi sampel } \\
\mathrm{fp} & =\text { faktor pengenceran } \\
\text { intercept } & =\text { hasil pembacaan dari grafik }
\end{array}
$$

\section{HASIL DAN PEMBAHASAN}

\section{Pembacaan Absorbansi terhadap Sampel Hasil Pemisahan Kromatografi Penukar Ion}

Kromatografi penukar ion dilakukan untuk memisahkan asam amino dari sampel yang telah dihidrolisis sebelumnya menggunakan $\mathrm{HCl} 6 \mathrm{~N}$ dan enzim protease. Asam amino tersebut yang kemudian akan dianalisis kadarnya. Elusi dilakukan oleh $\mathrm{NaCl}$. Dalam hal ini digunakan teknik kromatografi penukar ion (ion exchange). Kromatografi penukar anion menggunakan fasa diam Dietilaminoetanol (DEAE) dengan gugus aktif $\mathrm{N}^{+}\left(\mathrm{C}_{2} \mathrm{H}_{5}\right)_{2}$ dan eluen $\mathrm{NaCl}$ berbagai konsentrasi. Pada penambahan eluen $\mathrm{NaCI}$, ion $\mathrm{Cl}^{-}$akan menggantikan polipeptida atau asam amino bermuatan negatif yang semula terikat pada DEAE, sehingga polipeptida atau asam amino tersebut akan lepas dari matriks DEAE. Hasil pemisahan ditampung dalam fraksi-fraksi dan diukur kadar asam amino dengan spektrofotometer UV-VIS.

Hasil hidrolisis $\mathrm{HCl} \quad 6 \quad \mathrm{~N}$ menunjukkan bahwa pembacaan absorbansi tertinggi diperoleh pada konsentrasi eluen $\mathrm{NaCl}$ 0,2 dan 0,6 M (Gambar 1), sedangkan hasil hidrolisis enzim protease pembacaan absorbansi tertinggi pada eluen $\mathrm{NaCl} 0,2$ dan $1 \mathrm{M}$ (Gambar 2). Tidak ada perbedaan yang signifikan pada hasil pemisahan dengan kromatografi penukar ion ini, menunjukkan bahwa konsentrasi eluen $\mathrm{NaCl}$ tidak terlalu berpengaruh, sehingga untuk analisis selanjutnya digunakan hanya satu konsentrasi eluen. Faktor yang berpengaruh pada kromatografi penukar ion adalah kondisi $\mathrm{pH}$ pada resin dan sampel (Underwood, 2001). Oleh karena itu, pada penelitian ini ditambahkan buffer fosfat sitrat untuk mempertahankan kondisi $\mathrm{pH}$ agar tetap asam yaitu pada $\mathrm{pH}$ 5. Pada kondisi asam, anion $\mathrm{Cl}^{-}$dari $\mathrm{NaCl}$ akan bertukar sempurna dengan asam amino bermuatan positif.

\section{Kadar Asam Amino}

\section{Deret Standar Asam Amino Lisin}

Pembuatan deret standar dilakukan adalah untuk mengetahui konsentrasi larutan sampel dengan menggunakan persamaan regresi. Deret standar diukur absorbansinya dengan spektrofotometer UV VIS pada $\lambda 625 \mathrm{~nm}$. Hasil regresi linear yang diperoleh yaitu sebesar 0,9946 (Gambar 3), hasil tersebut menunjukkan bahwa deret standar asam amino lisin mempunyai nilai yang linear karena mendekati 1 (Harmita, 2004). Grafik deret standar menyatakan hubungan antara konsentrasi dengan absorbansi yang dihasilkan. 


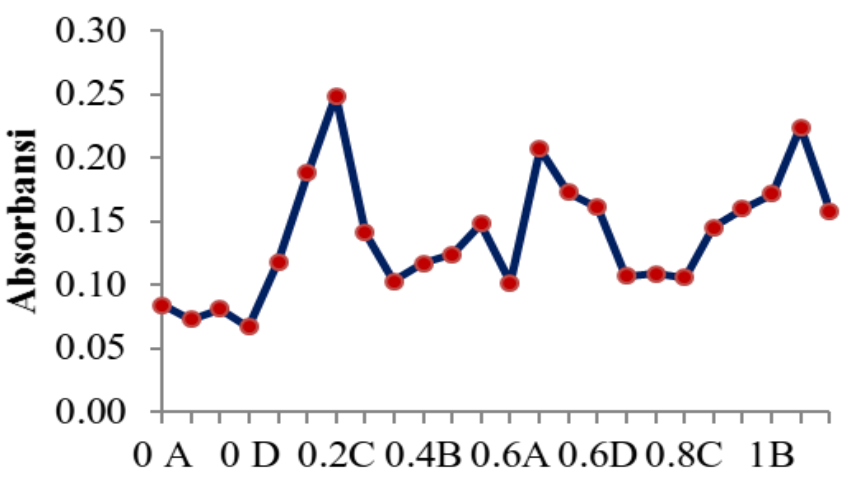

Konsentrasi $\mathrm{NaCl}(\mathrm{M})$

Gambar 1. Grafik Pembacaan Absorbansi Hasil Kromatografi Penukar Ion pada Sampel Hidrolisis LCPKS dengan $\mathrm{HCl} 6 \mathrm{~N}$.

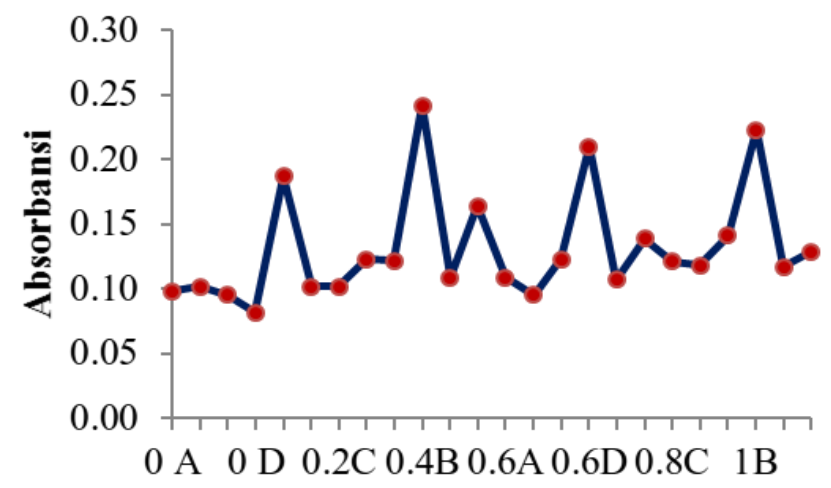

Konsentrasi $\mathrm{NaCl}(\mathrm{M})$

Gambar 2. Grafik Pembacaan Absorbansi Hasil Kromatografi Penukar Ion pada Sampel Hidrolisis LCPKS dengan Enzim Protease.

Keterangan:

Sumbu $\mathrm{x}$ : Konsentrasi $\mathrm{NaCl}$ yang mengelusi kolom.

Tanda A-D merupakan pengerjaan ulang sebanyak 4 kali.

Sumbu y : Pembacaan absorbansi pada spektrofotometer.

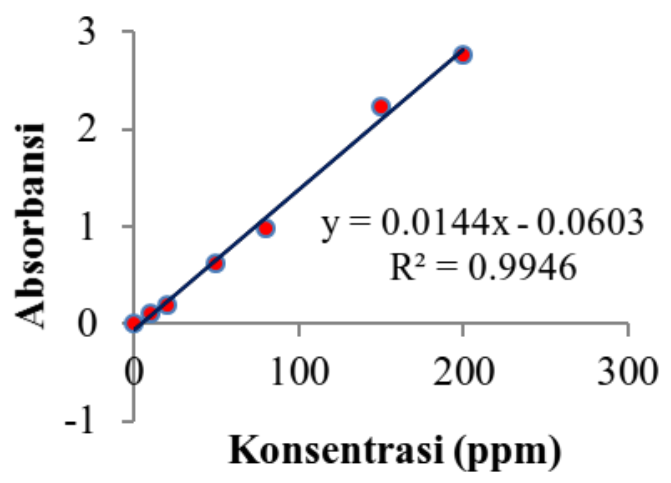

Gambar 3. Kurva Deret Standar Asam Amino Lisin 
<smiles>NCCCCC(N)C(=O)O</smiles>

Gambar 4. Struktur Asam Amino Lisin (Hart et al., 2003)

Asam amino lisin dipilih sebagai larutan standar baku karena struktur asam amino lisin sederhana yaitu memiliki satu gugus karboksil dan amino primer, sehingga mudah untuk bereaksi dengan ninhidrin. Semua asam amino yang ditemukan pada protein mempunyai ciri yang sama, gugus karboksil dan amino diikat pada atom karbon yang sama. Masing-masing berbeda satu dengan yang lain pada gugus $\mathrm{R}$, yang bervariasi dalam struktur, ukuran, muatan listrik, dan kelarutan dalam air. Beberapa asam amino mempunyai reaksi yang spesifik yang melibatkan gugus R. Lisin merupakan asam amino polar tanpa muatan pada gugus $\mathrm{R}$ (Hart et al., 2003).

\section{Kadar Asam Amino pada Sampel Hidrolisis LCPKS dengan $\mathrm{HCl}$ 6N dan Enzim Protease}

Kadar asam amino yang diperoleh pada sampel hasil hidrolisis LCPKS dengan $\mathrm{HCl} 6 \mathrm{~N}$ yaitu sekitar $0-8,82 \mathrm{ppm}$ (Tabel 1) dan sampel hasil hidrolisis enzim protease sekitar $0-4,31 \mathrm{ppm}$ (Tabel 2). Kadar asam amino yang diperoleh masih jauh dari yang diharapkan. Suplemen pada pakan ternak membutuhkan asam amino keseluruhan sekitar 7.140 ppm (Utomo dan Widjaja, 2004).

Sampel hidrolisat asam dan enzim protease mengalami perubahan warna biru keungungan setelah perlakuan pemanasan seperti pada deret standar, walaupun warna yang dihasilkan tidak sepekat deret standar. Reaksi antara ninhidrin dengan gugus amino primer membentuk warna ungu yang disebut juga dengan ungu Ruhemann karena ditemukan oleh Siegfried Ruheman pada tahun 1910 (Gambar 5). Prinsip dari reaksi ini adalah semua asam amino bereaksi dengan triketohidrindena hidrat atau yang disebut ninhidrin untuk membentuk aldehida yang lebih kecil dengan membebaskan karbon dioksida, amonia dan menghasilkan warna biru keunguan. Intensitas warna ini menunjukkan konsentrasi asam amino bebas, semakin pekat warna yang diperoleh semakin tinggi konsentrasi asam amino pada sampel (Rohman dan Sumantri, 2007).

Tabel 1. Kadar Asam Amino pada Sampel hasil hidrolisis LCPKS dengan HCl 6N

\begin{tabular}{ccc}
\hline No & Konsentrasi Eluen $\mathrm{NaCl}(\mathrm{M})$ & Kadar Asam Amino $(\mathrm{ppm})$ \\
\hline 1 & 0 & 0 \\
2 & 0,2 & 2,74 \\
3 & 0,4 & 3,27 \\
4 & 0,6 & 8,82 \\
5 & 0,8 & 3,79 \\
6 & 1 & 3,43 \\
\hline
\end{tabular}

Tabel 2. Kadar Asam Amino pada Sampel hasil hidrolisis LCPKS dengan Enzim Protease

\begin{tabular}{ccc}
\hline No & Konsentrasi Eluen $\mathrm{NaCl}(\mathrm{M})$ & Kadar Asam Amino $(\mathrm{ppm})$ \\
\hline 1 & 0 & 0 \\
2 & 0,2 & 3,79 \\
3 & 0,4 & 2,40 \\
4 & 0,6 & 4,31 \\
5 & 0,8 & 2,74 \\
6 & 1 & 2,75 \\
\hline
\end{tabular}




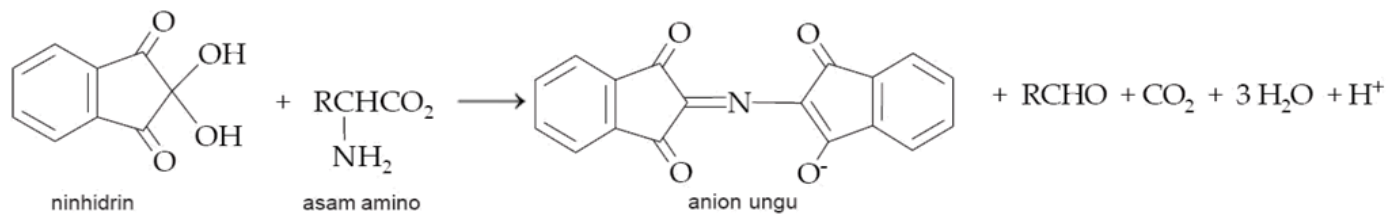

Gambar 5. Reaksi antara Asam Amino dengan Ninhidrin (Hart et al., 2003)

Pembacaan absorbansi yang bernilai kecil, dimungkinkan karena nilai limit deteksi dan limit kuantitasi pada alat spektrofotometer UV-VIS lebih besar daripada kadar asam amino yang terkandung dalam sampel. Limit deteksi atau Limit of Detection (LOD) adalah jumlah terkecil analit dalam sampel yang dapat dideteksi serta masih memberikan respon yang signifikan dibanding dengan blanko. Limit kuantitasi atau Limit of Quantity (LOQ) adalah kuantitas terkecil analit dalam sampel yang masih dapat memenuhi kriteria cermat dan seksama (Harmita, 2004). Sensitivitas pada alat spektrofotometer UV-VIS juga dapat menjadi pertimbangan yang menyebabkan hasil pembacaan absorbansi sampel bernilai kecil, sehingga setelah dihubungkan nilai slope dan intercept dari deret standar hasil kadar asam amino pun bernilai kecil.

\section{KESIMPULAN}

Asam amino dari limbah cair pabrik kelapa sawit dapat dipisahkan dengan cara kromatografi penukar ion dan dielusi dengan $\mathrm{NaCl}$ berbagai konsentrasi. Hasil pemisahan menunjukkan tidak ada perbedaan yang signifikan dari konsentrasi eluen $\mathrm{NaCl}$. Regresi linear yang didapat dari deret standar asam amino lisin sebesar 0,9946 menunjukkan bahwa linearitas alat masih masuk standar yaitu mendekati 1 . Kadar asam amino yang diperoleh pada sampel hasil hidrolisis LCPKS dengan $\mathrm{HCl}$ $6 \mathrm{~N}$ yaitu berkisar antara $0-8,82 \mathrm{ppm}$ dan pada sampel hasil hidrolisis enzim protease yaitu berkisar antara $0-4,31 \mathrm{ppm}$, hasil yang didapat masih jauh dari yang diharapkan.

\section{DAFTAR PUSTAKA}

Alaerts, G. 1987. Metode Penelitian Air. Usaha Nasional. Surabaya.

Anonimous. 2014. Ion-Exchange Chromatography. Workshop on Protein Purification and Characterization: 12-13.

Betty, J. S. 1996. Penanganan Limbah Industri Pangan. Kanisius. Yogyakarta.

Brown, J. E., I. Janet, K. Bea, L. Ellen, M. Maureen. 2005. Nutrition Through the Life Cycle. Wadsworth. USA.

Habib, M. A. B., F.M. Yusoff, S. M. Phang, K.J. Ang, S. Mohamed. 1997. Nutritional values of chironomid larvae grown in palm oil mill effluent and algal culture. Aquaculture. 158: 95-105.

Harmita. 2004. Petunjuk Pelaksanaan Validasi Metode dan Cara Perhitungannya. Majalah Ilmu Kefarmasian. 1:117-135.

Hart, H., L. E. Craine, D. J. Hart. 2003. Kimia Organik, Suatu Kuliah Singkat. Erlangga. Jakarta.

Hidayanto. 2007. Limbah Sawit sebagai Sumber Pupuk Organik dan Pakan Ternak. Seminar Optimalisasi Hasil Samping Perkebunan Kelapa Sawit dan Industri Olahannya sebagai Pakan Ternak. Samarinda.

Hidayati, A. 2007. Petunjuk Praktikum Kimia Analitik Dasar I. 
Laboratorium Kimia Dasar FT IAIN Walisongo. Semarang.

Mahajoeno, E., W. L. Bibiana, H. S. Surjono, Siswanto. 2007. Potensi Limbah Cair Pabrik Minyak Kelapa Sawit untuk Produksi Biogas. Biodiversitas. IX (1) : 48-55.

Rahardjo, N. 2005. Permasalahan Teknis Instalasi Pengolahan Air Limbah Pabrik Minyak Kelapa Sawit. Laporan Teknis. Jakarta.

Rohman, A dan Sumantri. 2007. Analisis Makanan. Gadjah Mada University Press. Yogyakarta.
Satria, H. 1999. Disain Instalasi Pengolahan Air limbah Industri Minyak Kelapa Sawit. Skripsi. Institut Teknologi Bandung. Bandung.

Underwood, A. L. 2001. Analisis Kimia Kuantitatif. Gramedia Pustaka Utama. Jakarta.

Utomo, B. N dan E. Widjaja. 2004. Limbah Padat Pengolahan Minyak Sawit sebagai Sumber Nutrisi Ternak Ruminansia. Jurnal Litbang Pertanian. XXIII (1). 